\title{
Measuring Minority Integration Conceptualization and Operationalization Issues
}

\begin{abstract}
Over the last decades, a large body of research has been dedicated to the causes of domestic conflict, mainly of the violent conflicts sometimes resulting in full-blown civil war. Most studies relied on objectively measurable empirical evidence, such as political power relations among social segments, their capabilities, and the geography of the country. Yet for warning and prevention we should be able to detect less obvious, less clear-cut, and/or more complex factors and forms of domestic conflict. The warning signs are very likely to show up in opinion surveys, but thus far no comprehensive research has been conducted to tap into this resource. The most resolute attempt to include survey data in conflict explanations came from the Indices of Social Development project (indsocdev.org), of which "Inclusion of Minorities" part-indicator included survey findings. Also, there were attempts to compare the patriotism levels of majority and minority groups (e.g. Elkins \&Stride 2007, Cebotari 2009). While an increasing gap between majority and minority patriotism may signal serious inter-group tensions, there is a great amount of uncertainty around which survey questions can adequately capture relevant attitude differences. Cross-national studies probing the often-used national pride question typically ran into disappointingly inconsistent findings, except for the basic pattern of national pride lessening in more developed countries (as expected by Inglehart). This paper argues for the use of the attachment measure instead of the pride measure, and shows that the former has higher response rates, while it also reduces the minority-majority answer gap in the developed countries. Yet in order to find actionable signals of increasing tension between a country's majority communal group and the minority groups, questions closer to the political reality of the country should be used. The World Value Surveys and ISSP inquire about the quality of democracy in the respondents' countries, and the paper shows that the minority-majority gap tends to meaningfully co-vary with the actual empowerment of the minorities in the respective countries. The finding is paralleled with an economy-based variation of the democracy assessments, showing that poorer respondents tend to give lower evaluation of democracy, except in case of enduring left-wing governments, when the wealthier do so.
\end{abstract}

\section{Contents}

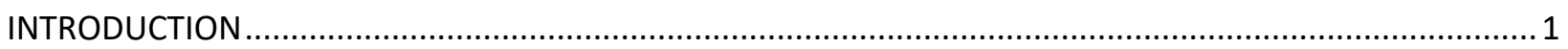

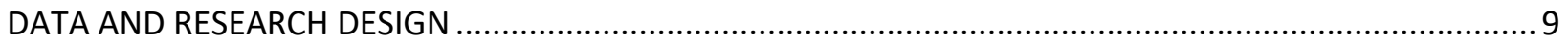



Triangulating Pride, Attachment, and Democratic-ness........................................................ 15

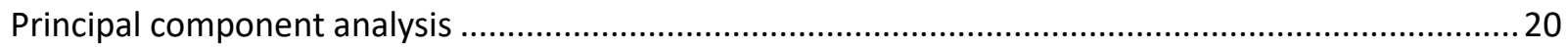

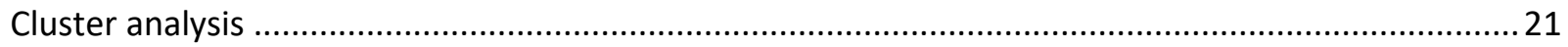

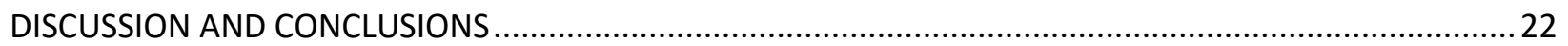

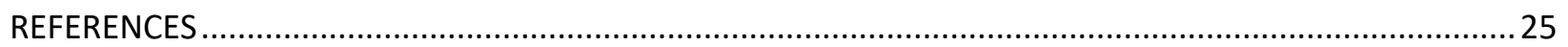




\section{INTRODUCTION}

The paper was born out of a quest for tools that may forecast upcoming domestic conflicts of communal nature, that is, conflicts among ethnic, linguistic, racial, religious, and regional groups. There has been a serious scholarly tradition studying the causes of communal conflict, and projects such as the Minorities at Risk and the Minority Rights Group's Peoples Under Threat rankings also undertook a predictive function, but they rely on hard-to-access indicators, which are produced by teams of scholars and are heavily contingent on funding and organizational opportunities.

Some authors had the idea to look at more easily available signals of troubled communal relationships, namely, to use the data produced by the ever-expanding survey literature. This is the way adopted by the International Institute of Social Studies (ISS), for instance, which included a mostly survey-based measure of "inclusion of minorities" in their Indices of Social Development (ISD). The project, which brought about a database currently covering 195 countries for the period 1990-2015, constructs the notion of social development as increasing social cohesion, trust, and justice. In 2007, Elkins \& Stride ${ }^{1}$, in 2009 , Cebotari ${ }^{2}$ argued that $^{2}$ national pride may be the measure of inter-ethnic cohesion, and looked into the determinants shaping the level of national feelings. More commonly, national pride is probed as a measure of national identity. Since the second half of the $20^{\text {th }}$ century, the scholarly interest in national identity is fueled not only by its importance for the peaceful co-existence of nations and communal groups, but also by the belief that it has an impact on social values and policy choices. This latter issue is variously articulated as support for the welfare state, pursuit of social justice, and/or support for distributive policies. Avoiding violent domestic conflicts, as well as avoiding the collapse of the democratic welfare state, confer a hot-button significance to the phenomenon of national identity, and the literature on it has been escalating over the last decades.

This paper did not aim at getting involved with the theory of nation, nationalism, and national identity. It started out to pursue a more practical goal. It asks that if we were to use an "early warning" system of survey results, to alert us to increasing inter-group tensions, which were the indicators to rely on? Has the ever-growing survey world produced suitable measures, and are they sensitive enough to capture significant changes in real time? Nonetheless, at the end of the query, we had to add a conclusion about the emphatically historical (thus constructivist) nature of people's national identity constructs.

The pioneers of using survey data for measuring and forecasting domestic tension, the ISD team, tend to rely on measures of inter-group tolerance. That is, they factor in questions about what kind of neighbors would be welcomed, and attitudes towards immigrants. These are suitable to capture inter-group animosity. Yet the most consequential animosity within societies

\footnotetext{
1 "First, survey data can measure discontent with the state before it is manifest in demonstrations. Survey-based measures of state attachment do not necessarily predict future protest or violence, but they may signal its potential" (Elkins \& Stride 2007, p. 695).

2 "It is argued in this paper that a strong feeling of national pride is a relevant measure for the idea of interethnic cohesion. Previous research has found that strong sentiments of national pride have a positive effect on state stability by making their citizens to be more involved in the nation (Evans and Kelly 2002, Smith and Jarkko 1998, Tilley and Heath 2007). Once the opinion of pride increases, the resulting feelings might turn to claims of superiority against "others" within the nation or against "others" outside the state (Brubaker 1996; Hjerm 1998). Since national pride is associated with both positive and negative outcomes, the need to understand its distribution across ethnic groups seems legitimate" (Cebotari 2009).
} 
develops not between random small groups that cannot tolerate each others' culture, but between a majority group commanding the state apparatus and minorities in underdog position. (Or a privileged communal minority commanding the state apparatus, and the excluded communal majority; but these situations are increasingly rare.) Thus in tests of inter-communal peace, we should focus on majority-minority relationships, which are qualitatively different from testing for group relationships, in general. They involve the state and its power relations, that is, a whole gamut of political attitudes, beyond the participants' opinion about each others' ancestry, language, and culture.

Papers that pursued a survey-based empirical assessment of minority-majority relationships usually relied on comparing the national identification and/or nationalism of majorities versus that of minorities. Most similar studies found a discrepancy between the two, named "ethnic asymmetry", with majorities reporting higher levels of national identity (Elkins \& Sides 2007, Cebotari $2009^{3}$, Staerkle et al 20104). Yet the studies also emphasize the complexity of the factors shaping this asymmetry. The gap seems to be influenced by a wide gamut of features of the social and political landscape, and in different countries (or country groups) the same causal pathways may play out in different ways. (For example, religiosity is in general positively related to nationalism, yet not in the Balkan countries.) The other stream of scholarship studying intercommunal cohesion, focused on support for redistribution policies, also has come to factor in idiosyncratic states of affairs, such as the velocity of immigration, and economic inequality ${ }^{5}$.

There are several intriguing questions arising with regard to the majority-minority asymmetry. Is it necessary? What about advantaged minorities? Or well-treated minorities? What difference is small, negligible, which is consequential? What can be done to bring the values closer?

However, before addressing all these real-world questions, we have to make some hard choices about how to measure and compare the relevant minority and majority opinions. That is, there are a few methodological issues to consider, which cluster in questions about (i) country sample; (ii) construction of "minority"; (iii) survey questions; and (iv) timeframe.

(i) The sphere of countries included in any international survey program is limited. The International Social Surveys (ISSP), which ask the most extended battery about national and ethnic attitudes in their "national identity" series (1995, 2003, 2013), included 23 to 33 countries in their three rounds. Faced with the possibility that there are cross-national (and/or crosscultural) variations of the national attitudes, the number of ISSP countries is too small for establishing well-grounded typologies. The World Value Surveys have a better geographical

\footnotetext{
${ }^{3}$ He studied the European Values Survey's (EVS) two rounds, ranging from 1994 to 2004, in 23 European countries, by factoring in the respondents' ethnic group, gender, age, education, religiosity, leftright political placement, life satisfaction, and attitudes toward authority. Yet it turned out that the relationships among the explanatory variables and the national identification outcome variable are deeply shaped by the country group to which the respondents belonged. Eventually he reported the findings along three European country groups.

4 "Our results confirm those obtained by Elkins and Sides (2007) for the World Values Survey, namely that there is a 'significant gap between the [national] attachment of majorities and that of minorities' ( $p$. 705), but show in addition the central role of country-level characteristics that measure social cleavages within countries, that is, social inequality and ethnic diversity."

${ }^{5}$ See, for instance, Steele 2016: "[My] regression models show that ethnic diversity itself is not negatively related, and may even be positively related, to support for redistributive social spending, which challenges the prevailing assumption about the divisiveness of ethnic diversity. There is one exception-support for redistribution may be lower when there have been large increases in the size of the immigrant population in a country, but only in countries in which economic inequality is particularly acute."
} 
coverage, while the best coverage is achieved by the regional Barometers, but some continents keep neglecting the national identity topic. We opted for the use of the WV Surveys, though they also fell short of our ideal country- and variable inventory.

(ii) Out of a larger gamut of possible communal features, such as ethnic, linguistic, racial, religious, regional, and tribal community boundaries, the literature on national identities tends to focus on ethnicity. This perspective seems to be deeply rooted in the legal approach to communal groups. International law allows for secession of ethnic groups only, and the jurisprudence of minority protection has also been molded on ethnic minorities. (In the Balkans, where communal tensions and strife have been ubiquitous for centuries, people of Muslim faith assumed an identity of Muslim ethnicity, for more political clout.) Linguistic differences are often used as proxies for ethnic differences, and they work well in the case of most countries, though in the post-Soviet world, millions of Russian-speakers are ethnic Byelorussians, for instance. The World Value Surveys use three communal questions: ethnic, linguistic, and religious. Yet not all countries ask all three questions, and some ask about race instead of ethnicity. There is no convincing tendency of the survey program to include minorities proportionally or by oversampling minorities ${ }^{6}$.

(iii) The most often used question to measure national identification/ national identity has been that of "national pride" (Cebotari 2009, Subhasish 2018). Yet several scholars recommend a more complex approach, that is, a measurement involving other indicators, as well. Elkins \& Stride (2007), as well as Miller \& Ali (2014), for instance, used the so-called "national attachment" question in parallel with the national pride question. This "national attachment" question has originally been introduced to compare the strength of different layers of the socioterritorial complex. It occurs in conjunction with questions about attachment to village/town, intra-state region, over-state continental or regional organizations, and the whole world ${ }^{8}$. It has the most importance in the EU, where the strength of the national identification is routinely being compared to the strength of identification as a European (or EU citizen). Miller \& Ali (2014) used a couple of additional measures, but the availability of those is much more restricted than that of the "pride" and "attachment" questions. For practical reasons, if we want to achieve wide geographical (and temporal) coverage of our study, we have to think about survey questions that occur frequently in programs of worldwide reach, primarily in the WVS and the regional Barometers. This paper will argue for the gradual phasing out of the "pride" question, keeping the "attachment" question, and completing it with indicators that draw on the political nature of the national (socio-territorial) identities. In advanced societies, the approval of a polity is increasingly dependent on its democratic character. The argument has been developed in the EU literature, where the rejection of the Union has regularly been tied to its "democratic deficit"9. This impelled us to explore the relationships between the perception of the countries' democracy level and measures of national identification.

\footnotetext{
${ }^{6}$ An illustration is given below: the US ethnic groups are White-Black-Hispanic-Multiracial-Other, without Native Americans and Asians, for instance.

7 The question reads "How proud are you to be [your nationality]", and the answers are Very proud, Quite proud, Not very proud, Not at all proud, typically coded from 1 to 4.

8 This question has a number of versions, but they all come with four answer possibilities, coded from the most attached to the least attached. Round 6 of WVS used the "I see myself as part of the [...] nation" formulation, with the answers coded as $1=$ strongly agree to $4=$ strongly disagree. Round 7 used the "How close do you feel to [your country]?" question, with the answers coded from 1=very close to $4=$ not close at all.

9 See, e.g. Schmitter 2000 for a handy summary of the pertinent concerns.
} 
(iv) This combination of measures also aims at coupling a phenomenon that is supposed to form and change quite slowly (the national identity/ identification, $\mathrm{NI}$ ) with a phenomenon that is more temporally related to the events taking place in a given country. Measurements of NI within the $\mathrm{EU}$, with the "attachment" question, corroborate that significant changes are possible within 10 to 20 year timeframes within the member states. The overall $\mathrm{NI}$, of the whole EU, stayed relatively stable between 2002 and 2020 , between 50 and 57 percent of the respondents claiming they were very attached to their country. Yet, in Germany, for instance, this proportion increased from $33 \%$ to $61 \%$ in approximately the same period, while in Hungary it decreased from $75 \%$ to $60 \%$, with most change occurring between 2006 and 2012 . The attached charts, produced by the Eurobarometer interactive feature, illustrate these trends.

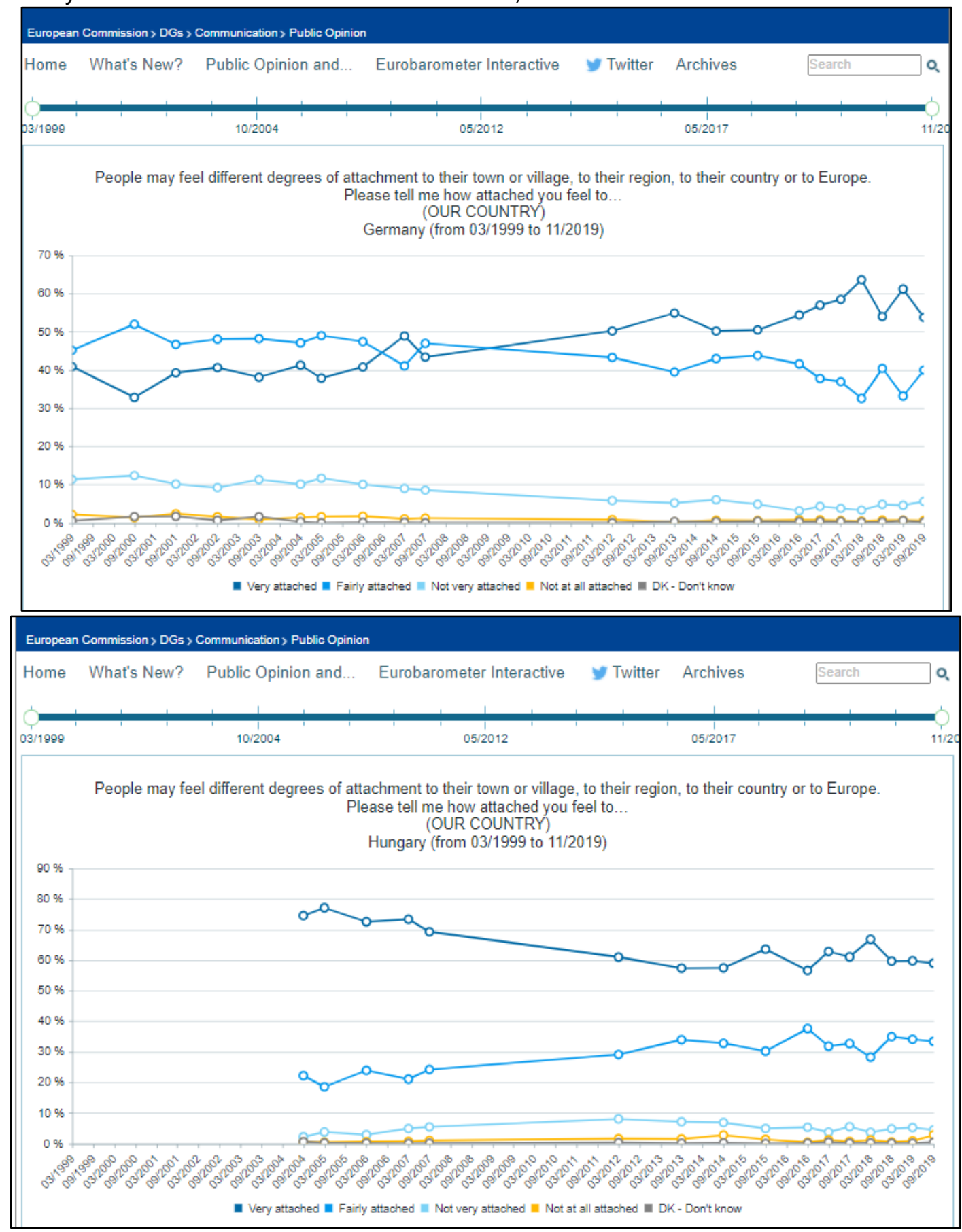


The main advantage of using surveys to diagnose inter-group tensions is their ability to return fast readings of the changes. We argue that there are survey questions that make this possible, and would like to attach an illustration for this.

The following tables summarize the responses to the WVS question: "How democratically is this country being governed today?", labeled "democratic-ness question". In the US, the time of the three rounds displayed corresponded to the Bush second, Obama, and Trump presidencies, respectively. There is a noticeable variation of the overall democratic-ness score $(6.34,6.46$, 6.05 , respectively, on the 10 -point scale ${ }^{10}$ ), but more importantly, the majority versus minority scores change significantly. Black Americans' assessment is a full rank below the whole population's average in Round 5 and 0.7 rank below the national average in Round 7, but almost a half rank above the national average in Round 6, during the Obama years. The White majority's answers display an opposite pattern ${ }^{11}$.

\begin{tabular}{|c|c|c|c|c|c|c|}
\hline WVS Round 5: 2005-2009 & $\begin{array}{l}\text { ALL US } \\
\text { Sample }\end{array}$ & Black African & $\begin{array}{l}\text { Spanish; } \\
\text { Hispanic }\end{array}$ & $\begin{array}{c}\text { White / } \\
\text { Caucasian } \\
\text { White }\end{array}$ & Other & Mixed races \\
\hline Not at all democratic & 4.9 & 13.3 & 5.7 & 3 & 9.8 & 3.1 \\
\hline 2 & 2.2 & 4.9 & 1.3 & 2 & 2.2 & 1.2 \\
\hline 3 & 4.1 & 6.1 & 7.4 & 3.4 & 0.4 & 1.2 \\
\hline 4 & 6.2 & 5.1 & 5 & 6.6 & 7.7 & 1.2 \\
\hline 5 & 16.6 & 19.9 & 21.5 & 14.8 & 21.9 & 21.6 \\
\hline 6 & 11.9 & 11.2 & 7 & 12.4 & 17.7 & 14.8 \\
\hline 7 & 15.7 & 9.7 & 13.1 & 17.7 & 7.2 & 18.8 \\
\hline 8 & 16.8 & 8.7 & 17.9 & 17.9 & 16.7 & 17.3 \\
\hline 9 & 10.3 & 7.9 & 7.2 & 11.8 & 3.1 & 6 \\
\hline Completely democratic & 6.7 & 5.2 & 7.1 & 7 & 2.9 & 10.1 \\
\hline Missing/Not asked & 2.6 & 5.2 & 2.2 & 1.9 & 7.4 & 3 \\
\hline No answer & 2.1 & 2.7 & 4.8 & 1.5 & 2.8 & 1.8 \\
\hline$(\mathrm{N})$ & 1.249 & 142 & 161 & 870 & 62 & 14 \\
\hline Mean & 6.34 & 5.32 & 6.12 & 6.58 & 5.61 & 6.67 \\
\hline Std Dev. & 2.31 & 2.69 & 2.4 & 2.17 & 2.32 & 2.11 \\
\hline Base mean & 1.19 & 131 & 150 & 840 & 55 & 14 \\
\hline
\end{tabular}

\footnotetext{
10 The democratic-ness measure in the World Value Surveys is ordinal. The tables presented here display the overall distribution of the answer frequencies, where "not at all democratic" corresponds to value 1 of the scale, and "Completely democratic" corresponds to value 10 of the scale. For easier comparisons, however, we tend to use the "mean" calculations, which are provided by the WVS online analytic feature, as well.

11 Yet it is to note that even the Whites' ranking of Trump is 0.03 below what they gave to Obama, and 0.29 below their ranking of Bush second. Against the backdrop of the January 6 events at the Capitol, it shows that Trump's reign was not associated with much democracy by any ethnic group in the US.
} 


\begin{tabular}{|l|r|r|r|r|r|r|}
\hline WVS Round 6: 2010-2014 & \multirow{2}{*}{$\begin{array}{c}\text { ALL US } \\
\text { Sample }\end{array}$} & $\begin{array}{c}\text { US: White, } \\
\text { Non-Hispanic }\end{array}$ & $\begin{array}{c}\text { US: Black, } \\
\text { Non-Hispanic }\end{array}$ & $\begin{array}{c}\text { US: Other, } \\
\text { Non-Hispanic }\end{array}$ & US: Hispanic & $\begin{array}{c}\text { US: 2+Races, } \\
\text { Non-Hispanic }\end{array}$ \\
\cline { 1 - 7 } Not at all democratic & 2.3 & 2.6 & 1.3 & 3.6 & 1.7 & 0 \\
\hline 2 & 1.9 & 1.7 & 0.1 & 3 & 4 & 0.8 \\
\hline 3 & 4.5 & 5.6 & 3.1 & 2 & 1.5 & 2.3 \\
\hline 4 & 7 & 7.9 & 5.1 & 2.5 & 4.8 & 8.4 \\
\hline 5 & 15.2 & 14.4 & 14.6 & 5.3 & 21.1 & 24.2 \\
\hline 6 & 14.3 & 15 & 13.5 & 12.6 & 12.3 & 9.6 \\
\hline 7 & 18 & 19.3 & 16.2 & 20.4 & 12.6 & 18.6 \\
\hline 8 & 18.6 & 18.4 & 17.6 & 18.1 & 19.7 & 21.8 \\
\hline 9 & 7.4 & 6.8 & 6.8 & 15.8 & 8.3 & 8.4 \\
\hline Completely democratic & 7.2 & 5.4 & 14.1 & 16 & 9.7 & 0 \\
\hline No answer & 3.5 & 2.8 & 7.5 & 0.5 & 4.3 & 5.9 \\
\hline (N) & $\mathbf{2 . 2 3 2}$ & $\mathbf{1 . 5 4 6}$ & $\mathbf{2 3 1}$ & $\mathbf{8 7}$ & $\mathbf{3 1 4}$ & $\mathbf{5 5}$ \\
\hline Mean & $\mathbf{6 . 4 6}$ & $\mathbf{6 . 3 2}$ & $\mathbf{6 . 9 4}$ & $\mathbf{7 . 2 2}$ & $\mathbf{6 . 5 9}$ & $\mathbf{6 . 3 9}$ \\
\hline Std Dev. & $\mathbf{2 . 1}$ & $\mathbf{2 . 0 8}$ & $\mathbf{2 . 0 6}$ & $\mathbf{2 . 2 9}$ & $\mathbf{2 . 1 7}$ & $\mathbf{1 . 6 7}$ \\
\hline Base mean & $\mathbf{2 . 1 5 5}$ & $\mathbf{1 . 5 0 3}$ & $\mathbf{2 1 4}$ & $\mathbf{8 6}$ & $\mathbf{3 0 0}$ & $\mathbf{5 2}$ \\
\hline
\end{tabular}

\begin{tabular}{|l|r|r|r|r|r|r|}
\hline WVS Round 7: 2017-2020 & \multicolumn{1}{|c|}{$\begin{array}{l}\text { ALL US } \\
\text { Sample }\end{array}$} & White & Black & $\begin{array}{c}\text { US: Other, } \\
\text { non-Hispanic }\end{array}$ & $\begin{array}{r}\text { US: Hispanic } \\
\text { US: Two plus, } \\
\text { non-Hispanic }\end{array}$ \\
\hline Not at all democratic & 5.1 & 2.6 & 14.9 & 4.1 & 7.6 & 7.3 \\
\hline 2 & 2.8 & 2.6 & 3.4 & 0 & 3.5 & 5.7 \\
\hline 3 & 5.7 & 5.6 & 6 & 7.3 & 5.7 & 4.6 \\
\hline 4 & 7.4 & 7.1 & 5.3 & 5.5 & 9.6 & 13.2 \\
\hline 5 & 18.8 & 16.9 & 22.3 & 25.3 & 21.6 & 19.7 \\
\hline 6 & 12.4 & 13.2 & 13.1 & 10.7 & 10.4 & 5.6 \\
\hline 7 & 17.6 & 20.2 & 8.6 & 21.2 & 11.7 & 20.3 \\
\hline 8 & 14.7 & 16.7 & 10.5 & 11.4 & 11.1 & 12.8 \\
\hline 9 & 6.3 & 7.2 & 4.3 & 7.3 & 4.8 & 2.6 \\
\hline Completely democratic & 6.7 & 6.1 & 8.4 & 5.6 & 8.3 & 5.3 \\
\hline Don't know & 0.2 & 0.1 & 0 & 0 & 1.1 & 0 \\
\hline No answer & 2.3 & 1.7 & 3.1 & 1.6 & 4.5 & 1.8 \\
\hline (N) & $\mathbf{2 . 5 9 6}$ & $\mathbf{1 . 6 7 1}$ & $\mathbf{3 0 7}$ & $\mathbf{1 1 6}$ & $\mathbf{4 0 9}$ & $\mathbf{9 3}$ \\
\hline Mean & $\mathbf{6 . 0 5}$ & $\mathbf{6 . 2 9}$ & $\mathbf{5 . 3 5}$ & $\mathbf{6 . 0 9}$ & $\mathbf{5 . 7}$ & $\mathbf{5 . 5 1}$ \\
\hline Std Dev. & $\mathbf{2 . 2 9}$ & $\mathbf{2 . 1 2}$ & $\mathbf{2 . 7 1}$ & $\mathbf{2 . 1 2}$ & $\mathbf{2 . 4 9}$ & $\mathbf{2 . 4}$ \\
\hline Base mean & $\mathbf{2 . 5 3 1}$ & $\mathbf{1 . 6 4 2}$ & $\mathbf{2 9 8}$ & $\mathbf{1 1 4}$ & $\mathbf{3 8 6}$ & $\mathbf{9 1}$ \\
\hline
\end{tabular}

That is, opinions about the democratic-ness of the country may be prompt and on point, yet there are two concerns to address. First, opinions about the democracy in a country may be, and indeed, they are, related to the interests of people making those assessments. And beyond the ethnic power relations, it's also the economic position that influences the assessments. In most countries, wealthy people are more convinced that their government works democratically, than the poor are. Conversely, there are clear cases of leftist-socialist governments getting more approval from poorer strata. The same democracy scores in the US, when disaggregated along subjective social class, show an enthusiastic reaction of the upper class to the Bush and Trump governments, and less enthusiasm during Obama. The pattern for the working class is inverse, but more disturbingly, the trust of the lower class in democracy is steadily decreasing over the three measurements, from 6.17 to 5.51 . Those who feel economically left behind, don't think the country is democratically - or well? - governed, which runs the risk that they become more tolerant towards authoritarianism. (Yet this is a story for a different paper.) 


\begin{tabular}{|c|c|c|c|c|c|c|c|c|}
\hline WVS Round 5: 2005-2009 & $\begin{array}{l}\text { ALL US } \\
\text { Sample }\end{array}$ & $\begin{array}{l}\text { Upper } \\
\text { class }\end{array}$ & $\begin{array}{c}\text { Upper } \\
\text { middle } \\
\text { class }\end{array}$ & $\begin{array}{c}\text { Lower } \\
\text { middle } \\
\text { class }\end{array}$ & $\begin{array}{c}\text { Working } \\
\text { class }\end{array}$ & $\begin{array}{l}\text { Lower } \\
\text { class }\end{array}$ & $\begin{array}{c}\text { Missing; } \\
\text { Unknow } \\
n\end{array}$ & $\begin{array}{c}\text { No } \\
\text { answer }\end{array}$ \\
\hline Not at all democratic & 4.9 & 0 & 1.6 & 4.6 & 8.8 & 4.8 & 2 & 0 \\
\hline 2 & 2.2 & 0 & 2.6 & 2.1 & 2.6 & 1.5 & 0 & 3.7 \\
\hline 3 & 4.1 & 0 & 4.4 & 2.9 & 3.4 & 13.7 & 1.1 & 2.5 \\
\hline 4 & 6.2 & 0 & 7.3 & 3.6 & 9.7 & 4.4 & 0 & 8.7 \\
\hline 5 & 16.6 & 15.4 & 9.4 & 19.1 & 22 & 14.5 & 1.3 & 29.3 \\
\hline 6 & 11.9 & 6.2 & 8 & 13.2 & 15.8 & 10.9 & 1.9 & 3.6 \\
\hline 7 & 15.7 & 8 & 16.7 & 21 & 11 & 13.3 & 11.4 & 0 \\
\hline 8 & 16.8 & 47.7 & 26.8 & 14.5 & 11.7 & 16.2 & 10.7 & 0 \\
\hline 9 & 10.3 & 0 & 11.7 & 10.8 & 9.3 & 12.2 & 7.5 & 0 \\
\hline Completely democratic & 6.7 & 22.6 & 10 & 5.9 & 5.3 & 7.2 & 0 & 0 \\
\hline Missing/Not asked & 2.6 & 0 & 0 & 0 & 0 & 0 & 64 & 0 \\
\hline No answer & 2.1 & 0 & 1.5 & 2.3 & 0.5 & 1.3 & 0 & 52.1 \\
\hline (N) & 1.249 & 14 & 301 & 413 & 362 & 89 & 51 & 18 \\
\hline Mean & 6.34 & 7.78 & 6.91 & 6.41 & 5.78 & 6.17 & 7.14 & 4.56 \\
\hline Std Dev. & 2.31 & 1.67 & 2.18 & 2.18 & 2.4 & 2.48 & 2.01 & 1.04 \\
\hline Base mean & 1.19 & 14 & 297 & 404 & 360 & 88 & 18 & 9 \\
\hline
\end{tabular}

\begin{tabular}{|l|r|r|r|r|r|r|r|}
\hline WVS Round 6: 2010-2014 & $\begin{array}{r}\text { ALL US } \\
\text { Sample }\end{array}$ & $\begin{array}{c}\text { Upper } \\
\text { class }\end{array}$ & $\begin{array}{c}\text { Upper } \\
\text { middle }\end{array}$ & $\begin{array}{c}\text { Lower } \\
\text { middle }\end{array}$ & $\begin{array}{c}\text { Working } \\
\text { class }\end{array}$ & $\begin{array}{c}\text { Lower } \\
\text { class }\end{array}$ & $\begin{array}{c}\text { No } \\
\text { answer }\end{array}$ \\
\hline Not at all democratic & 2.3 & 0 & 0.7 & 1.7 & 3.9 & 5.7 & 0.9 \\
\hline 2 & 1.9 & 7.8 & 1.6 & 2.8 & 1.5 & 0.4 & 0 \\
\hline 3 & 4.5 & 0 & 4 & 3.9 & 6.3 & 4.5 & 0 \\
\hline 4 & 7 & 2.2 & 5.3 & 7.6 & 6.5 & 14.9 & 3.6 \\
\hline 5 & 15.2 & 17.9 & 12 & 17.1 & 16.1 & 17.1 & 10.6 \\
\hline 6 & 14.3 & 8.3 & 12.4 & 14.2 & 17.5 & 11.4 & 7.9 \\
\hline 7 & 18 & 15.5 & 22.3 & 16.8 & 15.2 & 21 & 12.4 \\
\hline 8 & 18.6 & 9.5 & 23.1 & 18.7 & 17 & 11.4 & 9.6 \\
\hline 9 & 7.4 & 6.7 & 7.7 & 8.9 & 6.9 & 2.9 & 4.1 \\
\hline Completely democratic & 7.2 & 18 & 8.4 & 6.3 & 6.9 & 6.9 & 5.1 \\
\hline No answer & 3.5 & 14.1 & 2.5 & 2 & 2.2 & 3.7 & 45.8 \\
\hline (N) & $\mathbf{2 . 2 3 2}$ & $\mathbf{2 8}$ & $\mathbf{6 1 9}$ & $\mathbf{7 2 3}$ & $\mathbf{6 5 5}$ & $\mathbf{1 5 6}$ & $\mathbf{5 1}$ \\
\hline Mean & $\mathbf{6 . 4 6}$ & 6.86 & 6.83 & $\mathbf{6 . 4 3}$ & $\mathbf{6 . 2 4}$ & $\mathbf{5 . 8 9}$ & $\mathbf{6 . 7 6}$ \\
\hline Std Dev. & $\mathbf{2 . 1}$ & $\mathbf{2 . 4 4}$ & $\mathbf{1 . 9 4}$ & $\mathbf{2 . 0 8}$ & $\mathbf{2 . 1 9}$ & $\mathbf{2 . 2 1}$ & $\mathbf{1 . 8 8}$ \\
\hline Base mean & $\mathbf{2 . 1 5 5}$ & $\mathbf{2 4}$ & $\mathbf{6 0 4}$ & $\mathbf{7 0 9}$ & $\mathbf{6 4 0}$ & $\mathbf{1 5 1}$ & $\mathbf{2 8}$ \\
\hline
\end{tabular}

\begin{tabular}{|c|c|c|c|c|c|c|c|c|}
\hline WVS Round 7: 2017-2020 & $\begin{array}{l}\text { ALL US } \\
\text { Sample }\end{array}$ & $\begin{array}{l}\text { Upper } \\
\text { class }\end{array}$ & $\begin{array}{c}\text { Upper } \\
\text { middle } \\
\text { class }\end{array}$ & $\begin{array}{c}\text { Lower } \\
\text { middle } \\
\text { class }\end{array}$ & $\begin{array}{c}\text { Working } \\
\text { class }\end{array}$ & $\begin{array}{l}\text { Lower } \\
\text { class }\end{array}$ & $\begin{array}{l}\text { Don't } \\
\text { know }\end{array}$ & $\begin{array}{c}\text { No } \\
\text { answer }\end{array}$ \\
\hline Not at all democratic & 5.1 & 0 & 3.6 & 4.9 & 6.1 & 9.7 & 0 & 4.1 \\
\hline 2 & 2.8 & 0 & 2.7 & 3.4 & 2.6 & 2.6 & 0 & 0 \\
\hline 3 & 5.7 & 1.2 & 6.1 & 5 & 6.7 & 6 & 0 & 0 \\
\hline 4 & 7.4 & 9.2 & 7.7 & 7.1 & 8.1 & 6.9 & 0 & 0 \\
\hline 5 & 18.8 & 8.5 & 9.5 & 21.9 & 21.9 & 29.8 & 0 & 30.8 \\
\hline 6 & 12.4 & 19.5 & 12.2 & 13.8 & 11.5 & 9 & 0 & 7.1 \\
\hline 7 & 17.6 & 16.5 & 22.9 & 16.4 & 15.2 & 11.8 & 0 & 9.3 \\
\hline 8 & 14.7 & 14.2 & 19.8 & 14.2 & 11.5 & 10.4 & 0 & 0.6 \\
\hline 9 & 6.3 & 5.5 & 8.8 & 7.2 & 3.5 & 2.7 & 0 & 0 \\
\hline Completely democratic & 6.7 & 25.5 & 5.5 & 4.5 & 10.1 & 8 & 0 & 3.3 \\
\hline Don't know & 0.2 & 0 & 0 & 0.2 & 0 & 1.3 & 100 & 0 \\
\hline No answer & 2.3 & 0 & 1.2 & 1.4 & 2.8 & 1.8 & 0 & 44.8 \\
\hline (N) & 2.596 & 33 & 764 & 929 & 643 & 189 & 1 & 37 \\
\hline Mean & 6.05 & 7.33 & 6.4 & 5.95 & 5.9 & 5.51 & 0 & 5.5 \\
\hline Std Dev. & 2.29 & 2.05 & 2.21 & 2.22 & 2.4 & 2.45 & 0 & 1.88 \\
\hline Base mean & 2.531 & 33 & 754 & 914 & 625 & 183 & 0 & 20 \\
\hline
\end{tabular}

Second, the relationship between national identification and beliefs about democracy is not straightforwardly, well established in the literature, and our inquiry here will show the caveats to 
apply when searching for this relationship. Some co-variance cannot be unseen, though. With our previous example, the Americans' national pride decreased from Round 5 to Round 7, as the trust in democracy did, as well, yet the African-American group recoded a peak in-between the endpoints, during the Obama era.

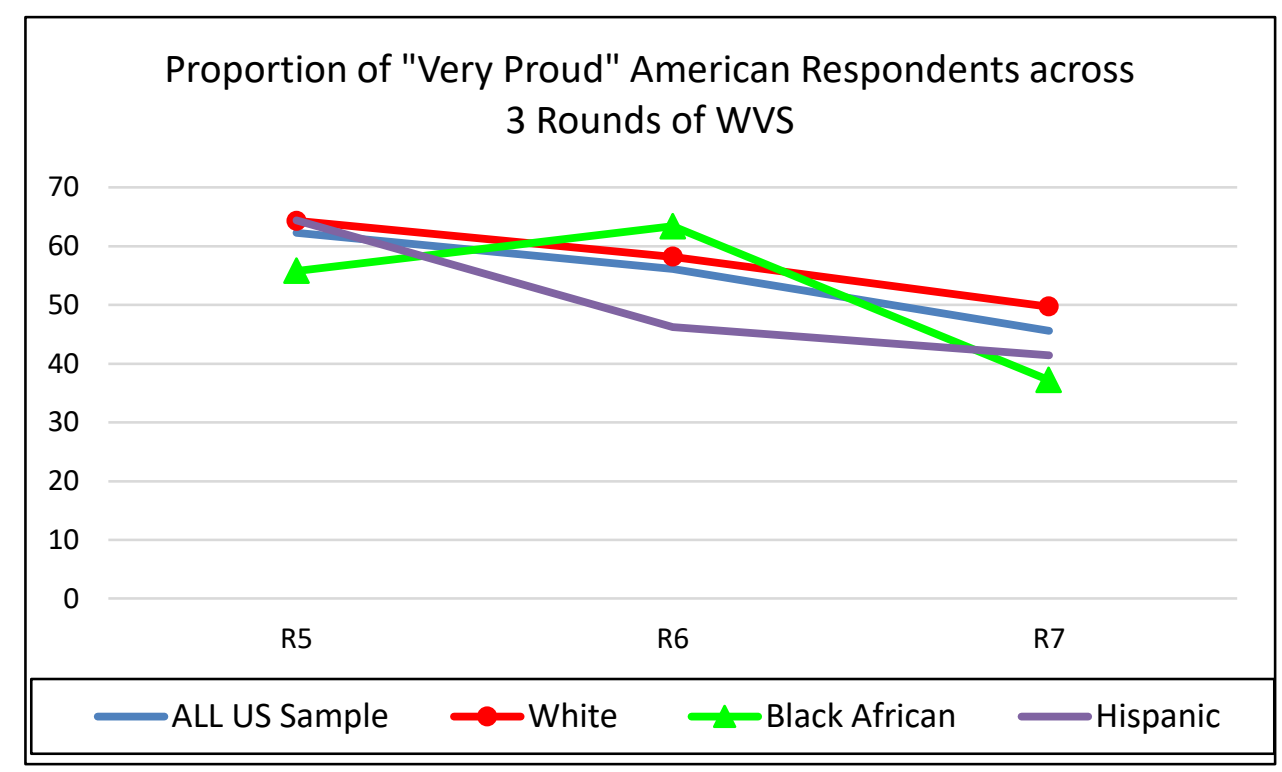

There have been several studies about the co-variation of national pride (Pride) with individual demographic features, such as age, education, and religiosity. Inglehart's postmaterialist theory expected these to be related to nationalism, namely, the first two inversely, and the third positively. In general, these expectations have been confirmed, with small, localized exceptions. Researchers in general expect the relationship between Pride and wealth to be positive, though this has not come across in surveys as clear-cut as the previous correlations (Shulman 2003). From our perspective, if Pride increases with the respondents' socio-economic status, then we have more reasons to expect the co-variance of the opinions about democratic-ness and Pride. Yet there are several cross-cutting factors, which blur the picture we may get from surveys. First, the wealth of the country, or more exactly, its development level, is inversely related to the level of Pride (Inglehart 1997). Second, nationalist sentiments are influenced not only by wealth levels, but also by its distribution, with increasing economic inequality triggering a "rallying around the flag" effect that boosts Pride in some countries (Solt 2011). And third, individual wealth is related to individual education, which, in its turn, is inversely related to Pride.

Searching the literature and observing the real world, the evolution of national identification and its dimension of nationalist sentiments comes across as a very complex issue even when we factor in only individuals and states, as most of the modernization and post-modernization scholarship tends to do. Yet in the real world, the existence of sub-national groups further complicates the relationships. Communal heterogeneity has often been said to have negative impacts on countries (slowing economic development, destabilizing polities, hindering redistributive policies), and closest to the topic of this paper, minorities are considered to be less loyal to their country of citizenship than majorities are. Within the limits of the data available from opinion surveys, we will try to address the concurrent impact of country development level and communal diversity on the evolution of nationalist sentiments. 


\section{DATA AND RESEARCH DESIGN}

The research question animating this project is to find survey measures that dependably indicate mounting inter-communal tensions, specifically the minorities' feeling left behind and not integrated in their country of citizenship. The literature points toward the "ethnic asymmetry" of the national identification measures, which makes these measures the most likely candidate. Yet there is no consensus about which particular question serves the purpose best. Most scholars have relied on the "national pride" question, but a significant minority opts for the use of the "national attachment" question, which, in its turn, comes in a number of distinct formulations ("how close", "how attached", "feel part of..."). We would suggest to consider one more measure: the respondents' opinion about the democratic-ness ${ }^{12}$ of their country at a given time.

The theoretical reasons to do so are related to the essence of the socio-territorial identities, particularly of the national identity. They are community- and polity-related. National identity specifically refers to the institution of state and the respondent's relationship with that state in their capacity as a citizen. The caveats of constructing national identities as attitudes with a primarily political content lie with the scholarship's long-established distinction between "ethnic" and "civic" nationalisms ${ }^{13}$. One could argue that "ethnic" nationalisms are not state-oriented, but ethnic group (or "ethnie"-) related. There is some merit to the claim, yet the argument is increasingly obsoleting. As a historical fact, ethnic nationalisms have been typical to Europe only; and the par excellence example of it, Germany, can be shown to have switched to a much more civic, even post-civic understanding of national identity. And even if someone constructs Germany as the community of German-descendant German-speaking people, as opposed to the commonwealth of German citizens, their own role in the community, their own possibilities to influence public affairs, that is, their perception of democracy-- may be of utmost importance in shaping their attitudes toward it. It may make the difference between "my community" and "the ethnic group I was accidentally born into".

In case of minorities, national identification has always suffered from the particular schism between identification with the state of citizenship (eminently "civic") and identification with an ethnic group. The latter is an ethnic identity, but not actually "nationalism", as it is not citizenship-based ${ }^{14}$.

Descriptions of civic nationalisms generally involve a concept of state as a Westphalian entity, defined by its relationships with other states, all with distinct national interests in the international arena. This concept goes hand in hand with feelings of national pride, unconditional submission to the national interest, including a willingness to self-sacrifice for it.

\footnotetext{
${ }^{12}$ Sadly, this unusual "democratic-ness" is a better one-word descriptor of the pertinent survey question than the traditional idiom "democracy". The question we refer to asks "how democratically is this country being governed today?" in the WVSs. In ISSP 2014, it asks three questions about today, 10 years ago, and 10 year in the future. That is, the questions are not really about whether the long-term institutions of democracy are in place in the country. The questions ask about the way the current power-holders operate those institutions, and they assume that democracy has levels/ gradations that vary at least in 10yr cycles. "Democratic-ness" seems to be a good term to capture the idea that the quality or level of democracy in a country may vary across years, and that variation is related to the people in charge of the polity.

${ }^{13}$ Greenfeld \& Jonathan 2007 explain the origins and implications of this distinction.

${ }_{14}$ Double and multiple citizenships are a symptom showing the obsolescence of ethnic nationalisms, deemed to be more exclusionary than the civic version.
} 
With increasing international interdependence, strengthening international institutions, and regional integrations, the idea of zero-sum-ness of state relations has been challenged. But more consequentially for the "civic" nation concepts, democracy has become an overarching ideal of the domestic institutional arrangements, a highly sought value in itself. People expect to be part of the country's self-governing, and have a say in the definition of national interest. They are grateful to, and proud of the countries that have successful democratic institutions.

Against this backdrop of changing socio-territorial identities, this paper set out to explore two hypotheses:

1. Attachment to a country is a better measure of the majority-minority ("ethnic") gap of national identities than national pride; and

2. The nationalist sentiments (pride and attachment) are related, and possibly shaped, by beliefs about the democratic-ness of the country. That is, beliefs about how democratically is a country being governed may be good complementary indicators of nationalist sentiments.

The hypotheses involve three types of survey questions: about national pride, national attachment, and democratic-ness. Yet they also require decent possibilities to separate majority and minority respondents, and questions about the socio-economic status are a further bonus. Since we contend that national identity and the feelings through which we measure it are historically evolving phenomena, we wanted to involve a large sample of countries with various economic, social, political, and cultural features. The idea is that changes of national identification across countries with different development level highlight its historical evolution. For the study of short-term changes, repeated waves of the surveys can be used, but socioterritorial identities are deemed to be slowly changing constructs.

With all these restrictions, two waves of the World Value Surveys were selected, and the ISSP 2014 round as a control. The workflow involved three main steps:

1. Generating country-level and communal group level measures.

2. Unstructured exploration of the country-level indicators, that is, cross-country comparisons.

3. Principal component and cluster analysis of the data from the two WVS rounds.

The first - and hardest - empirical task was disaggregating minority and majority respondents in each survey, in each country. The WVS series asks three questions pertinent to communal features. It asks about the ethnic group, language at home, and religious denomination. Yet there have been a significant number of countries in each round that omitted the ethnic question, and also a number that asked it by creating irrelevant groups. For instance, some East European countries gave the answer possibilities along race, not ethnicity, which only distinguished a handful of new immigrants, not the significant ethnic minorities in those countries. Language at home was asked in all countries, and in some it made up for the lack of the ethnic question, for instance, in Turkey and Romania. Yet it failed to make up for omitted ethnic questions in the case of the Latin-American countries, for instance, where the indigenous, even if they identify as indigenous, mostly speak Spanish (or Portuguese). Religious denomination has also been asked in all countries, and in some cases, when the ethnic cleavages coincide with the religious cleavages, as in Cyprus, minorities defined along the lines of religious belief could make up for the lack of ethnic majority-minority differentiation. Yet today in a majority of countries the religious cleavages are not salient, or they are not significantly related to the more salient ethnic, linguistic, and regional divides. 
The other important hurdle was the small number of minority respondents. In some countries, the minority population is small, and WVS did not aim at oversampling them. On the contrary, sometimes serious undersampling happened. In the case of a $2.8 \%$ minority, their fair share would have been 28 out of 1000 respondents. Yet in Australia, where $2.8 \%$ of the population is believed to be indigenous, there were only 2 respondents identifying as Indigenous, out of a generous sample of almost 2000 . This is about $0.1 \%$, and was obtained by using the weights meant to correct for sample representativeness issues. Consequently, in Australia it's only the Indigenous who may be accounted for as "minority," thus the cumulative number of minorities is also 2, and Australia had to be dropped from the comparison of minority versus majority attitudes. There were a few other countries with minority counts below 10, also dropped from consideration. (Moreover, we should be cautious about any group smaller than 30 .)

\begin{tabular}{|c|c|c|c|c|}
\hline Australia & $\begin{array}{c}\text { National pride } \\
\text { mean }\end{array}$ & $\begin{array}{c}\text { Feel close } \ldots \\
\text { mean }\end{array}$ & National pride \# & Feel close ...\# \\
\hline Other & 1.34 & 1.63 & 38 & 40 \\
\hline AU: Australian/English speaking & 1.51 & 1.69 & 1245 & 1265 \\
\hline AU: European & 1.56 & 1.69 & 164 & 188 \\
\hline AU: South Asian: Indian, Pakistani, etc. & 1.67 & 1.68 & 68 & 74 \\
\hline AU: East Asian: Chinese, Japanese etc. & 1.62 & 2.04 & 108 & 149 \\
\hline AU: Southeast Asian: Thai, Vietnamese, Malaysian, etc & 1.18 & 1.18 & 10 & 12 \\
\hline AU: Arabic, Central Asian & 1.77 & 1.68 & 32 & 29 \\
\hline AU: Aboriginal and/or Torres Strait Islander & 1.20 & 1.20 & 2 & 2 \\
\hline Total & 1.53 & 1.71 & 1667 & 1759 \\
\hline
\end{tabular}

Most Australian ethnic groups (South Asians, East Asians) are new immigrants, and had to be excluded from the majority-minority contrasts. Some of these classification choices were hard and disputable, but immigrants to developed countries are legitimately separated from "old" minority groups. Newcomers chose to get into that country, and they are normally very enthusiastic about being there. It's only the second, and even more typically, the third generation, which starts to compare their fortune not with the people's left in the country of origin, but with that of the majority group in the target country. This comparison is essential for developing a minority consciousness, and not all immigrants or immigrant groups go through it. In the very "melting pot" countries, successful immigrants assimilate to the majority group, and only retain some leisure-time cultural group consciousness. As a rule of thumb, we drew the divider line at about 50 years of en masse presence of the group in their country of residence. For instance, Turks in Germany were classified as minority, while post-Yugoslavs in Sweden were not.

To summarize, it was impossible to create majority and minority groups in 20 cases out of the 109 country samples included in the two rounds of WVS ${ }^{15}$. As for the 2014 round of ISSP, there were 8 countries out of 34 in which the minority-majority comparison could not be performed. The difficulty of coding the communal groups into minority and majority, while also counting the number of respondents from each group, prevented the use of the method of entering the minority-majority codes directly in the dataset and calculating the group means afterwards. Instead, group means (and group frequencies) were written out from the untouched original dataset, and the minority-majority-immigrant-other codes added to the output file transported

\footnotetext{
15 In addition, two of the 89 countries where a minority-majority comparison of the Pride and Attachment values was possible, had to be dropped from the comparison of democracy group means. (Uzbekistan because they did not ask the democracy question, and Bangladesh because of case number issues.) New Zealand did not ask about attachment to the country.
} 
into Excel. After the coding was completed, weighted averages were calculated for all majority and minority groups in each country separately, which then resulted in country-level measures.

Further methodological choices and steps were determined by the reliance on country-level indicators, which otherwise, was a necessity not only because of minority-group creation issue. In cross-national research, there is always a doubt about the value of pooled results. WVS provides weights that equalize the size of the country samples, but is it really defensible to set Andorra on the same footing with China, population-wise? The inverse method, to make the samples proportional with the size of the population of the country they represent, works better, but only in case of well-defined country groups, such as the European Union. When a survey program relies on a non-random sample of all countries, there is no way to claim that the totality of the respondents are a representative sample of the world population. Of course, we may calculate grand totals and averages, and the results may be suggestive, but not decisive proofs for any general claim.

Here are some all-across-the-sample results from WVS Round 6\&7, and from ISSP 2014, all calculated by using the within-country weights only. The measures displayed - and actually all measures used in this survey - apply the methodological shortcut of using ordinal variables as interval variables. This is easier to defend in the case of 10-point democracy scale (coded from least democratic towards most democratic) and also for similarly 10-point income scales, and less easy to defend in the case of the 4-point "Proud" and "Attachment" scales. Yet the paper does not aim at establishing, let alone measuring, causal relationships, and does not use regression analysis, where we have advanced techniques to address the ordinal variables. These analyses rely on comparing the level of some features, as well as the strength of the relationships among those features. These tests are quite byzantine to carry out and they run into serious interpretation issues when done by ordinal levels ${ }^{16}$.

\begin{tabular}{|c|c|c|c|c|c|c|c|}
\hline WVS Measurements & Whole sample & 1st world & $\begin{array}{c}\text { (Post)comm } \\
\text { unist }\end{array}$ & Asia-Oceania & $\begin{array}{c}\text { Latin } \\
\text { America }\end{array}$ & MENA & SS Africa \\
\hline Democracy_mean & 6.010 & 6.417 & 5.837 & 6.751 & 5.845 & 5.199 & 5.928 \\
\hline Dem * Income & 0.091 & .121 & .127 & .031 & .038 & .097 & .109 \\
\hline Dem * Rightwing & 0.108 & .048 & .130 & .196 & .071 & .182 & .171 \\
\hline Diff. Dem MJ_min & 0.262 & .387 & .064 & .241 & .019 & .574 & .524 \\
\hline Proud_mean & 1.515 & 1.737 & 1.568 & 1.293 & 1.461 & 1.384 & 1.330 \\
\hline Attached_mean & 1.596 & 1.695 & 1.513 & 1.693 & 1.672 & 1.409 & 1.545 \\
\hline Diff.PR (min-MJ) & 0.117 & .091 & .195 & .148 & .002 & .207 & .105 \\
\hline Diff.ATT (min-MJ) & 0.131 & .117 & .236 & .034 & .047 & .242 & .116 \\
\hline
\end{tabular}

\footnotetext{
${ }^{16}$ For instance, we could compare the proportions of "very proud", "proud", "somewhat proud," "not proud at all," and missing answer ("DK"/no response/refused) in the countries, but how to address phenomena such as that Country A has both more "very proud" and "not proud at all" answers, while Country B has more "quite proud"? The by-level comparisons downgrade the ordinal indicator to a nominal scale, and lose the information contained in its ordinal quality.
} 


\begin{tabular}{|c|c|c|c|c|c|}
\hline ISSP 2014 Measures & $\begin{array}{c}\text { Top-Bottom } \\
\text { self- } \\
\text { placement }\end{array}$ & $\begin{array}{c}\text { Highest } \\
\text { completed } \\
\text { education } \\
\text { level }\end{array}$ & $\begin{array}{c}\text { Q44 Political } \\
\text { self- } \\
\text { placement: } \\
\text { Left - Right }\end{array}$ & $\begin{array}{c}\text { Q58 } \\
\text { Democracy in } \\
\text { [COUNTRY]: } \\
\text { today }\end{array}$ & $\begin{array}{c}\text { Q59 } \\
\text { Democracy in } \\
\text { [COUNTRY]: } \\
10 \text { years ago }\end{array}$ \\
\hline Q58 Democracy in [COUNTRY]: today & $.213^{\star *}$ & $.122^{* *}$ & $.081^{\star \star}$ & & \\
\hline Q59 Democracy in [COUNTRY]: 10 years ago & $.203^{* *}$ & $.069^{* *}$ & $.052^{* *}$ & $.559^{* *}$ & \\
\hline Q60 Democracy in [COUNTRY]: 10 years from now & $.153^{\star \star}$ & $.107^{* *}$ & $.083^{\star *}$ & $.706^{\star \star}$ & $.329^{\star *}$ \\
\hline Highest completed education level & $.287^{\star *}$ & & & & \\
\hline Q44 Political self-placement: Left - Right & $.081^{* *}$ & $-.047^{* *}$ & & & \\
\hline
\end{tabular}

The numbers in the tables above allow for the conclusion that in a majority of the countries included in the surveys, there are the wealthier people who trust the office-holders to govern democratically, rather than the poorer respondents. The ISSP survey measured very strong correlations between subjective SES and assessment of democracy, at Pearson's above 0.2. The pooled $6^{\text {th }}$ and $7^{\text {th }}$ Round of the WVSs gives the relationship at a lower, but still highly significant Pearson value for the totality of the respondents (0.09), and above 0.1 in 3 regions out of 6 .

The ISSP results also evidence the historical character of the democracy assessment. The present state is much stronger related to both past and future democratic-ness $(.559, .706)$ than past and future are related between them (.329). This indicates that people's opinion about democracy in their country is likely to change with the changes brought by electoral cycles, and can be expected to be responsive to significant social and political events.

The table with the WVS results evidence regional ${ }^{17}$, rather than historical trends. We would expect the $1^{\text {st }}$ World respondents to give their democracy the highest rankings, but AsiaOceania topped them. And third came in the Sub-Saharan countries. Asia-Oceania and Africa are the regions highest on national pride, as well; yet the First world is not the second there. It is, notably, the very last. ${ }^{18}$ The developed world is the region that displays the weakest national sentiments on both measures, but it is also one of the two where the respondents are significantly more attached to their countries, rather than proud of it. Otherwise, their national

17 The regional groups included the below countries:

$1^{\text {st }}$ World: Andorra_7, Australia, Australia_7, Cyprus, Cyprus_7, Estonia, Germany, Germany_7, Greece_7, Hong Kong, Hong Kong_7, Japan, Japan_7, Macau_7, Netherlands, New Zealand, New Zealand_7, Poland, Puerto Rico_7, Romania, Romania_7, Singapore, Slovenia, South Korea, South Korea_7, Spain, Sweden, Taiwan, Taiwan_7, United States, United States_7

(Post)communist: Armenia, Azerbaijan, Belarus, China, China_7, Georgia, Kazakhstan, Kazakhstan_7, Kyrgyzstan, Kyrgyzstan_7, Russia, Russia_7, Serbia_7, Tajikistan_7, Ukraine, Ukraine_7, Uzbekistan, Vietnam_7

Asia-Oceania: Bangladesh_7, India, Indonesia_7, Malaysia, Malaysia_7, Myanmar_7, Pakistan, Pakistan_7, Philippines, Philippines_7, Thailand, Thailand_7

Latin-America: Argentina, Argentina_7, Bolivia_7, Brazil, Brazil_7, Chile, Chile_7, Colombia, Colombia_7, Ecuador, Ecuador_7, Guatemala_7, Haiti, Mexico, Mexico_7, Nicaragua_7, Peru, Peru_7, Trinidad \&T, Uruguay

MENA: Algeria, Egypt, Egypt_7, Iran_7, Iraq, Iraq_7, Jordan, Jordan_7, Kuwait, Lebanon, Lebanon_7, Libya, Morocco, Palestine, Qatar, Tunisia, Tunisia_7, Turkey, Turkey_7, Yemen

SS Africa: Ethiopia_7, Ghana, Nigeria, Nigeria_7, Rwanda, South Africa, Zimbabwe, Zimbabwe_7

That is, the frequency in those groups was, in the above order, $31,18,12,20,20$, and 8.

18 The measures we labeled here "Proud" and "Attached" were both coded with 1 for the most enthusiastic answer ("very proud" and "very attached"/"very close"), and 4 for the least enthusiastic answer ("not at all proud" and "not at all attached'/ "not at all close"). Thus lower values mean more national pride and more attachment to the country. 
attachment is a stronger feeling than national pride, and we may hypothesize that their national identity is structured around amity and cohesiveness, rather than an outward-looking sentiment involving competition with, and possibly exclusion of, non-nationals.

Finally to this preview of the survey data, the WVS summaries show that minorities are not always more distrustful of the political elite than the majorities. There were a few countries in which minorities ranked their countries' democratic-ness higher than their respective majorities, and at the region-level, in Latin America the difference is a small 0.019, followed by the group's labeled "(Post)communist" at a value of 0.064 . Yet the overall pattern is that minorities are less contented with the democracy in their country. The cross-regional variation invites more serious inquiries into the country-level features that shape the differences, including the possibility of dominant minorities, ethnic power relations, and more generally, the economic, social, and cultural status of minorities.

The reason for involving comparisons of poor versus wealthy opinions in the study of minority versus majority opinions is that the effects of significant, life-shaping disadvantages on people's attitudes towards the overarching institutions that frame their life is in all odds very similar. If poor people feel left behind by their country and rate its democratic-ness lower than the wealthy, then communal minorities suffering of any of discrimination, politically powerlessness, cultural oppression, or a combination of these, may be expected to react in the same way. And ostensibly, most communal minorities are economically less well-off than their respective majorities, a worldwide pattern with some, but rare exceptions.

This is the backdrop against which we can interpret the last two rows of the WVS table, showing that the group mean differences of the Pride and Attachment measures are all positive values. This means that in all regions majority respondents are prouder and more attached to their country than the minority respondents. The difference is sometimes very small $(0.002,0.034$, $0.047)$, yet in aggregates it's invariably in the same direction. At the same time, there are a number of countries where minorities do not differ significantly from, or are more patriotic than the majorities. The paper will try to detect these cases and find an explanation for the "irregular" patterns.

\section{COMPARISONS, FACTORS, CLUSTERS}

The focus of these analyses is on the World Value Surveys' Pride and Attachment questions, thus it is the case that we have a brief look at the respondents who answered these questions.

In round 6 and 7 , there were a total of 154,941 respondents giving valid answer to the Pride question, and 156,124 giving valid answer to the Attachment question, as calculated with the within-country population weights. This suggests that there were a total of 1,183 more people answering the Attachment question than the Pride question. Yet the calculus is not this simple. The Pride question allowed for a (volunteered) answer that "I am not a [...] national", and there were, obviously, hundreds of people answering that way ${ }^{19}$. On the other hand, the Attachment question was not asked in New Zealand in the $6^{\text {th }}$ round, when 799 respondents answered the Pride question. Thus we added the number of "I am not national" respondents to the Pride answers by country, and recalculated the Attachment-Pride difference that way.

19 These answers were coded as missing for our group mean calculi, together with the "Don't know"-s. 


\begin{tabular}{|l|r|r|}
\hline \multicolumn{1}{|c}{ Region } & $\begin{array}{c}\text { Adjusted Attached- } \\
\text { Pride frequency } \\
\text { difference }\end{array}$ & $\begin{array}{c}\text { \# Cntries in } \\
\text { region }\end{array}$ \\
\hline 1st world & 239 & 30 \\
\hline (Post)communist & 48 & 18 \\
\hline SS Africa & -47 & 8 \\
\hline Asia-Oceania & -64 & 12 \\
\hline MENA & -131 & 20 \\
\hline Latin America & -150 & 20 \\
\hline
\end{tabular}

*New Zealand was excluded from this calculus

With this adjustment, the Pride-answerers actually outnumber the Attachment-answerers by $104^{20}$ in the whole sample. Yet the interesting thing about the difference is its by-country and regional distribution. In the $1^{\text {st }}$ World and the (Post)communist group, there were more people answering the Attachment question, than answering the Pride question. In other regions, the Pride-answerers were in majority. This is the same divide as in the case of the regional means on the two questionnaire items. Some respondents are both more comfortable in answering the Attachment question than the Pride question and more attached to, than proud of, their country $^{21}$. It seems that there is a cognitive-affective convergence forming around the idea that the right question to ask is "how attached" and the right sentiment to have is attachment, rather than pride.

Further, we may be interested to know whether the people who are proud of their country are the same as the people who are attached to it, or not? Strangely, it really depends on the country. There were 26 countries out of 109 (or 108, by discounting New Zealand Round 6) where the correlation between the Pride and Attachment answers reaches very strong, above 0.4 Pearson-correlation values. And there were five countries where the correlation did not reach significant correlation values at all ${ }^{22}$. Taken by regions, the correlation is strong in the MENA area, $1^{\text {st }}$ World, (Post)communist world, and weak in Asia-Oceania and Sub-Saharan Africa, with Latin-America in-between. It seems that longer experience with the nation-state arrangement leads to more coherence of the two identity sentiments.

\section{Triangulating Pride, Attachment, and Democratic-ness}

The measure for assessing the democratic-ness was introduced in this study in order to test its potential for signaling minority-majority divergence and animosity. In a first step, however, we analyzed the relationship between these subjective assessments and some objective measures of democracy in the respondents' country. The World Bank's Governance Indicator set, the Vdem project's indicators, the Freedom House rankings and the Polity2 measure were used. The

\footnotetext{
20 The correction actually "overcorrects" by at least 83 respondents. New Zealand's Round 7 survey had an Attachment-answerer surplus of 43, all lost from Round 6. And the 2108 non-nationals would have had their own share of invalid answers on the Pride question. For nationals, the combined total of DK-s, "no answer"-s, and spoiled answers was about $1.8 \%$. This percentage of non-nationals means about 40 respondents.

${ }^{21}$ Because of the difficulties of creating minority versus majority groups in each country, some conjectures have not been rigorously tested. Yet it seems that, at least in the countries in the positivedifference regions, minorities are particularly more at ease at addressing the attachment item, as compared to the pride item.

22 Bangladesh_7, Ethiopia_7, Myanmar_7, Rwanda, and Thailand_7.
} 
subjective evaluations seem to be mostly related to the World Bank's Government Effectiveness indicator (0.5 Pearson), but show convincing above 0.3 , highly significant correlations with all WGBI measures. Out of the V-Dem project's democracy indicators, it's the "v2x_egaldem" scoring the highest, thus in subsequent analyses these were included ${ }^{23}$.

In the next step, the relationship between democracy answers and "Pride" and "Attachment" answers have been studied. In 83 countries out of the 109, democratic-ness and pride can be shown to be significantly related, at Pearsons ranging from a high -0.77 in Sweden to a pale 0.085 in Georgia. In 21 countries, there is no significant relationship between the two, while in Pakistan_7 and Egypt the inverse relationship emerged as significant: there people may be proud of their nationality despite their perceiving the country as non-democratic ${ }^{24}$. The surprising factor is that there are four First World countries among those where the relationship between democracy and pride is insignificant: Germany_7, Australia, Cyprus, and Slovenia. Yet in all four, beliefs about democracy are significantly related to the Attachment values. So are they in four other countries: Armenia, Philippines_6, Philippines_7, and Rwanda. That is, in eight countries where the Democracy ${ }^{\star}$ Pride relationship is insignificant, the

Democracy*Attachment relationship is significant. In contrast, in Pakistan_7 and Egypt_6 the inverse relationship emerged with regard to Attachment, as well ${ }^{25}$. In general, the relationships between democracy assessments and Attachment are weaker than between the democracy and Pride, and both are the strongest in the developed country group. The $1^{\text {st }}$ World country group shows an average Pearson of -0.145 for Dem*Attached, and -0.181 for Dem*Pride. The whole-sample averages of these relationships are -0.094 and -0.138 , both significant. The countries with the strongest Dem*Attached relationships are the United States_7 (-0.284), Germany (-0.280), and Spain (-0.253). Looking at the first 20 countries on this list, we find only five countries belonging to other country groups, another proof that democracy and attachment are the most related in the $1^{\text {st }}$ world country group. As for the democracy and pride relationship, the toplist of 20 strongest relations contains 9 not- $1^{\text {st }}$ world countries.

Relying on country-level indicators, we may find one more proof of the relationship between democracy assessments, pride, and attachment. This shows up if we compare the crosscountry variation of the majority-minority gap on these three measures. In countries with gap between democracy assessments, we typically find gaps between the Pride and Attachment means, as well, of the majority versus minority groups. Out of 64 countries where majorities ranked higher the democratic-ness than the minority group, in 48 countries the pride values were also on behalf of the majorities, and the attachment values in 47 countries $^{26}$. In the 23 countries where minorities gave higher ranking to democratic-ness, the pride ranking was 12 times on behalf of minorities, as well, with one case undecided because of the small respondent numbers. These counts are convincing, but miss the magnitude of the differences, thus calculating some correlation coefficients may help to get more insight about these relationships.

\footnotetext{
${ }^{23}$ Again, there is not enough data at hand, and going after the facts would ramble too far from the original research question, but it seems that people tend to evaluate democracy as a function of the most common everyday life experiences. The answers show somewhat less concern with Voice and Accountability (WBGI) than with having the government run its institutions smoothly, and less concern with the electoral arrangements than with egalitarian democracy.

24 In three countries the democratic-ness question was not asked.

25 It seems that the inverse relationship may occur at various democratic-ness levels, as Egyptians are among the most critical nations (4.58), while the Pakistani are quite contented with their government (6.74).

${ }^{26}$ There were two countries where the gap in democracy assessment could be measured, but the pride gap could not, because of the small number of respondents. As for Attachment, there were also two countries lost to small respondent numbers, plus New Zealand, where the question was not asked.
} 
The Pearson coefficients turn up as significant in the case of the democratic-ness gap with the pride gap, and also with the attachment gap in the case of the linguistic minorities. (The values are in the range of $0.309-0.388$ across about 90 countries.)

It may be worthwhile to analyze the countries where the minorities ranked democracy higher than the majorities, to gain some insight about what makes minorities positive towards their country of citizenship. In the following table, the "Notes" are some hypotheses about the reasons. Haiti seems to be a quite clear case, there an advantaged minority gave the favorable answers. In the next three countries in the list (Bolivia_7, Romania_7 and US), there were minority leaders in power at the time of the survey. Singapore is known for its ethnic powersharing structures, and something similar happens in Pakistan, as well. Iran looks like a transitional case between the "minority power" group and the next cluster of mainly LatinAmerican countries, where it seems that it's the leftist/ populist policies favored by the mostly indigenous minorities. Three cases, Armenia, Zimbabwe and Libya suggest that minorities place great hopes in a turn for better when a long-ruling leader inimical to their causes is toppled. As a unique case, Serbia's minorities have probably reacted with enthusiasm to the start of the EU accession talks. 


\begin{tabular}{|c|c|c|c|c|c|}
\hline Country & Region & $\underset{\min }{\text { Diff.Dem_MJ- }}$ & Diff.PR & Diff.ATT & Notes \\
\hline Haiti & Latin America & -0.26 & -0.02 & 0.16 & Advantaged minority (light skinned) \\
\hline Bolivia_7 & Latin America & -0.89 & -0.08 & -0.07 & Evo Morales president (Indigenous) \\
\hline Romania_7 & 1st world & -0.49 & 0.47 & 0.08 & $\begin{array}{l}\text { Klaus lohannis president (ethnic minority); } \\
\text { Hungarian party on and off govt. positions }\end{array}$ \\
\hline United States & 1st world & -0.35 & 0.05 & 0.15 & Barack Obama president (minority) \\
\hline Singapore & 1st world & -0.26 & -0.28 & -0.13 & Ethnic power-sharing structures in place \\
\hline Pakistan_7 & Asia-Oceania & -0.65 & 0.09 & 0.09 & $\begin{array}{l}\text { Federation, territorial autonomies, Punjabi } \\
\text { majority (of } 45 \% \text { ) have their own province. } \\
\text { Federal govt. often dominated by minorities } \\
\text { (e.g. Sindhi, Muhajir) }\end{array}$ \\
\hline Pakistan & Asia-Oceania & -0.50 & -0.09 & 0.02 & $\begin{array}{l}\text { Federation, territorial autonomies, Punjabi } \\
\text { majority (of } 45 \% \text { ) have their own province. } \\
\text { Federal govt. often dominated by minorities } \\
\text { (e.g. Sindhi, Muhajir) }\end{array}$ \\
\hline Iran_7 & MENA & -0.36 & -0.07 & -0.03 & $\begin{array}{l}\text { Larger majorities have their own provinces (E- } \\
\text { W Azerbaijan, Kurdistan); general social } \\
\text { security rights are enacted in constitution }\end{array}$ \\
\hline Nicaragua_7 & Latin America & -1.59 & -0.09 & 0.24 & Daniel Ortega president (Sandinista left) \\
\hline Ecuador_7 & Latin America & -0.52 & -0.05 & 0.04 & $\begin{array}{l}\text { Lenin Moreno started out as a continuator of } \\
\text { Correa (dem. socialist), but then embarked on } \\
\text { neoliberal policies }\end{array}$ \\
\hline Mexico & Latin America & -0.49 & 0.03 & & Lopez Obrador (PRI --> Morena, left-wing) \\
\hline Colombia_7 & Latin America & -0.26 & -0.09 & -0.03 & $\begin{array}{l}\text { Iván Duque Márquez, centrist, since 2018, } \\
\text { following Nobel-prize winner Calderon }\end{array}$ \\
\hline Uruguay & Latin America & -0.10 & -0.08 & -0.13 & Tabaré Vázquez (leftist Broad Front) president \\
\hline Armenia & (Post)communist & -0.72 & -0.08 & 0.40 & $\begin{array}{l}\text { Nikol Pashinyan PM after } 2018 \text { "velvet } \\
\text { revolution" (ousts national-conservatives, } \\
\text { brings in populists) }\end{array}$ \\
\hline Zimbabwe_7 & SS Africa & -0.53 & 0.22 & 0.24 & $\begin{array}{l}\text { Survey after the fall of Mugabe (2017), } \\
\text { Ndebele } 17 \% \text { minority making great hopes }\end{array}$ \\
\hline Serbia_7 & (Post)communist & -0.10 & -0.02 & 0.41 & $\begin{array}{l}\text { President Vucic an unreliable populist, but } \\
\text { Serbia started EU accession talks in } 2015\end{array}$ \\
\hline Macau_7 & 1st world & -0.02 & 0.13 & 0.36 & 23 respondents from 4 small minorities \\
\hline Slovenia & 1st world & -2.01 & & 0.33 & $\begin{array}{l}25 \text { respondents from } 5 \text { small (below-1\%) } \\
\text { minorities }\end{array}$ \\
\hline Vietnam_7 & (Post)communist & -0.90 & -0.03 & -0.20 & $\begin{array}{l}\text { Respondents from small, } 1 \% \text { minorities each } \\
\text { (Thai \& Muong highlanders) }\end{array}$ \\
\hline Russia_7 & (Post)communist & -0.25 & 0.21 & -0.09 & $\begin{array}{l}\text { Well integrated - } 55 \% \text { of ethnic minorities } \\
\text { speak Russian at home }\end{array}$ \\
\hline Libya & MENA & -0.03 & -0.04 & -0.02 & $\begin{array}{l}91 \text { Tamazight speakers who ethnically identify } \\
\text { as Arabs, not Berber; Survey taken } 2 \text { yrs after } \\
\text { Gaddafi (seen as assimilationist) }\end{array}$ \\
\hline Ghana & SS Africa & -0.27 & -0.01 & -0.03 & $\begin{array}{l}\text { All ethnic groups composed of tribes, plus } \\
\text { cross-cutting religious lines, ethnic territories; } \\
\text { English official, } 9 \text { govt sponsored languages; } \\
\text { no real ethnic ID and animosity among } \\
\text { national/indigenous groups. Nationalism } \\
\text { directed towards non-nationals. }\end{array}$ \\
\hline Azerbaijan & (Post)communist & -0.03 & 0.43 & 0.66 & $\begin{array}{l}18 \text { Talysh (1.3\%) gave very high marks; } \\
\text { Russian, Lezgin and Avaric-speakers more } \\
\text { critical than Azeri; Armenians not asked }\end{array}$ \\
\hline
\end{tabular}


There are, however, a few cases when it's not some political feature that is the most likely explanation, but the possible causes are either deep-seated in the communal landscape of the country, or a possible artifact brought about by the small sample size (or a combination of the two). The examples suggest three "real" possible explanatory factors:

i. Size of the minority. In Vietnam, there are 53 recognized minorities. Most are below $1 \%$ of the population, and even the largest is below $2 \%$, though numerically they may reach about 700,000 . Respondents came only from two, around-1\% minorities. In Macau and Slovenia the minority groups are very small, both numerically and as a percentage of the population ${ }^{27}$. We may hypothesize that small minorities don't regard themselves as a player in the national political arena, and if their local administration is satisfactory, they are prone to give high rankings to the country's domestic politics in general.

ii. The group's "distance" from the majority. In the Russian Federation, there are several minority groups that distinguish themselves from Russians because of their Kazakh, Moldovan, or Azeri ancestry, yet they speak Russian at home ${ }^{28}$ in about $55 \%$ of the cases. In Libya, an inverse pattern emerged: all 91 Tamazight speakers identified ethnically as Arab.

iii. Complex and fluid group boundaries. Ghana's ethnic landscape is complicated, with quite granular basic groups, clans and tribes, which come together in alliances that may have cross-cutting features (e.g, region and religion), and of which common language formation has not been supported politically. After independence, Ghana opted for English as an official language, and nine local languages were selected out of more than 100 to serve as languages of elementary education. Beginning with grade 7, all basic subjects are taught in English ${ }^{29}$.

Azerbaijan's results are due to 18 Talysh respondents, who ranked its democracy extremely high. All other groups in the sample (Russians, Lezgins and Avars) were more critical than the Azeri majority. Yet the real artifact in this survey finding is that no Armenian was in the sample probably because they live in the breakaway region Nagorno-Karabach.

The table above also includes the Pride and Attachment differences found in the respective countries. In 14 cases out of 23 , the minorities are also prouder of their country than the majorities, and in one case, equally proud. Yet Attachment seems to be less related to democracy assessments, in 13 cases the majorities feel more attached, with one equal result. There are 8 countries in which all measures point in the same direction, and one more, Russia, where minorities rank higher on the democracy indicator and Attachment, but lower on Pride.

\footnotetext{
${ }^{27}$ Macau's traditional non-Chinese minority is that of people of Portuguese descent, not really exceeding $1 \%$ any longer. The jurisdiction's official census lumps all non-Chinese and non-Portuguese residents in an "other" category, and there are reasons to believe that the largest "other" group is the Filipino, of whom proportion may reach $3 \%$, but in the small Macau that's only about 15,000 people. In the sample, there are 14 ethnically South Asian respondents, but none of them speaks Filipino or South-Asian languages. This indicates quite assimilated minorities.

${ }^{28}$ Russia's Round 7 sample had 168 respondents identifying themselves with an ethnic minority, but only 76 respondents who don't speak Russian at home.

${ }^{29}$ Yet in 2000, under the pressure of increasing immigration to Ghana, the naturalization of immigrants was made dependent on speaking a Ghanaian indigenous language.
} 


\section{Principal component analysis}

A simple, unrotated principal component (PC) analysis was carried out based on 109 cases (countries) and 16 measures, by asking for the PCs higher than eigenvalue 1. SPSS found six factors cumulatively explaining $75.4 \%$ of the variation in the data. The table below uses color coding to highlight the measures that weigh heavily on a factor.

\begin{tabular}{|c|c|c|c|c|c|c|}
\hline & \multicolumn{6}{|c|}{ Component } \\
\hline & 1 & 2 & 3 & 4 & 5 & 6 \\
\hline Correlation Attachment ${ }^{\star}$ Pride & .292 & .649 & .044 & -.057 & .112 & -.484 \\
\hline Difference Attachment_Pride & -.452 & -.632 & .410 & .242 & -.227 & .103 \\
\hline Proud_scale_mean & .613 & .388 & -.097 & .442 & .048 & -.057 \\
\hline Attached_scale_mean & .081 & -.367 & .396 & .745 & -.225 & .066 \\
\hline Correlation Democracy ${ }^{\star}$ Pride & -.525 & -.115 & -.245 & -.008 & .508 & .187 \\
\hline Correlation Democracy ${ }^{\star}$ Attached & -.651 & -.051 & -.320 & -.039 & .170 & .371 \\
\hline Correlation Democracy ${ }^{\star}$ Soc.class & -.592 & .011 & .471 & -.084 & .340 & -.316 \\
\hline Correlation Democracy Income & .335 & .152 & -.732 & .151 & -.279 & .259 \\
\hline Democracy_scale_mean & .323 & -.549 & .258 & -.462 & -.054 & .116 \\
\hline Communal Pride Difference (min-MJ) & -.078 & 671 & .484 & .027 & -.109 & .340 \\
\hline Communal Attachment Difference (min-MJ) & -.144 & .748 & .343 & .076 & .001 & .163 \\
\hline Communal Democracy Difference (MJ-min) & .248 & .373 & .370 & -.161 & .084 & .499 \\
\hline EPR15_exclpop & -.216 & .033 & -.136 & .525 & .467 & .102 \\
\hline V2x_egaldem & .709 & -.170 & .097 & -.157 & .381 & .250 \\
\hline wbgi_gee & .841 & -.326 & .164 & -.077 & .112 & .083 \\
\hline Life Expectancy & .617 & -.284 & .101 & .255 & .405 & -.084 \\
\hline Variance explained (\%) & 22.910 & 17.576 & 11.723 & 9.129 & 7.237 & 6.776 \\
\hline
\end{tabular}

The first PC, which explains $23 \%$ of the variation, is a clear-cut "modernization indicator". It shows that countries that are high on the objective, external measures of democracy and welfare, are comparatively low on Pride values, yet the measured national pride tends to be consistent with the democracy assessments and the Attachment values. The correlation between Attachment and democracy is also emphatic in this factor, as it is the correlation between democracy assessment and social class, plus income. Countries with these features are also relatively free of communal issues, both on objective measures (EPR's "excluded population") and on subjective measures, that is, the survey responses.

The second factor ( $17.6 \%$ of variance explained) brings together features that may be labelled as "patriotism in undemocratic countries". Low on objective democracy and welfare values, also on subjective ranking of democratic-ness, the PC is high on Attachment, and low on Pride, though these latter two are reasonably well related on individual respondent level. This constellation seems to emerge against a backdrop of emphatic communal (majority-minority) differences, in the expected, classic sense. (That is, majorities have better opinion about their country than the minorities).

The third PC (11.7\% explained) gets most of its content from the measures of Democracy's correlation with income and social class. Compared to the first PC, this is "anti-modernization", 
that is, it negates the democracy-income relationship that exists in the first factor. It also associates low Attachment and high Pride values with emphatic communal differences of all ranking answers, also in the expected sense.

The fourth PC is, in a way, the antithesis of the second. Objective and subjective undemocraticness are paired with low attachment to the country, and low national pride. May be called a "no democracy, no patriotism" factor...

The fifth factor brings us back in the more developed world, among countries with relatively high life expectancy and objective democracy measures, though with large communal groups excluded from power. It tells us that in these conditions the democracy assessments are not well related either to national pride or to the SES of the respondents.

Finally, the sixth $\mathrm{PC}$ also ties communal issues to an antithetical relationship between the Democratic-ness and Attachment measurements, and also to Attachment's antithetical relationship with Pride. Yet here the "communal issues" are ranking gaps: differences between minorities and majorities in assessing democratic-ness, and being proud and attached, respectively. Also, the higher Democratic-ness assessments come from respondents positioned higher on the social ladder.

\section{Cluster analysis}

The principal components defined by the artificial intelligence of SPSS seem to have confirmed the patterns intuitively detected in the data at hand, mainly in the correlation matrices. We have challenged the "artificial intelligence" with one more test, asking for a K-means clustering of the 109 countries based on the same 16 measures as those included in the PC analysis. Because of the 6 PC-s, we opted to ask for 6 clusters, as well.

The output from the exercise includes (i) the list of the cluster centers; (ii) the cluster assignment of each country; (iii) the distance of each country from the cluster center, which ranged from 0.5 to 3.6. The latter information has been simplified by creating three intervals to measure the country's distance from the cluster center, value 1 encompassing 0.5 to 1.5 , value 2 encompassing 1.5 to 2.5 , and value 3 encompassing 2.5 to 3.6 .

The table with the cluster centers was colored in order to make sense of the numbers. The highest two values on each row were colored red, and the lowest two were colored blue, with a difference of a shade between the first and the second placed cluster.

We arranged the clusters in the order indicated by the objective development and democracy (D\&D) measures Life expectancy, wbgi_gee, and v2x_egaldem, which also tend to correlate strongly among them. The fourth objective measure included, relating to the condition of minorities, is only weakly correlated with the democracy indicators, and not correlated with Life expectancy in this sample of countries.

The black frames in the bottom corners indicate the country clusters transpiring as most developed (red) and least developed (blue) based on the objective D\&D measures. Visibly, the levels of Pride, Attachment, their mutual correlation, as well as their correlation with democraticness, and the latter's correlation with the respondents' social class (red frame), are very different in those two groups. That is, people's national identity constructions change with the society in 
which they live, and the most important differentiating factor is the country's developmental level, together with the democracy level.

\begin{tabular}{|c|c|c|c|c|c|c|}
\hline Final cluster centers & 6 & 2 & 3 & 1 & 4 & 5 \\
\hline Correlation Attachment* Pride & .361 & .283 & .301 & .259 & .306 & .245 \\
\hline Difference Attachment_Pride & -.101 & .207 & .098 & .026 & .079 & .055 \\
\hline Proud_scale_mean & 1.777 & 1.424 & 1.485 & 1.750 & 1.412 & 1.402 \\
\hline Attached_scale_mean & 1.698 & 1.631 & 1.582 & 1.776 & 1.491 & 1.457 \\
\hline Correlation Democracy ${ }^{\star}$ Pride & -.208 & -.102 & -.150 & -.214 & -.086 & -.089 \\
\hline Correlation Democracy*Attached & -.179 & -.079 & -.083 & -.129 & -.061 & -.021 \\
\hline Correlation Democracy ${ }^{\star}$ Soc.class & -.127 & -.041 & -.039 & -.014 & -.044 & -.030 \\
\hline Correlation Democracy*Income & .102 & .110 & .066 & .123 & .106 & .064 \\
\hline Democracy_scale_mean & 6.99 & 5.57 & 5.97 & 5.94 & 5.82 & 5.13 \\
\hline Communal Pride Difference (min-MJ) & -.01 & .03 & .12 & .10 & .26 & .06 \\
\hline Communal Attachment Difference (min-MJ) & .04 & .12 & .08 & .13 & .28 & .09 \\
\hline Communal Democracy Difference (MJ-min) & .626 & .047 & .169 & .323 & .452 & -.189 \\
\hline EPR15_exclpop & .051 & .127 & .180 & .005 & .177 & .010 \\
\hline v2x_egaldem & .719 & .460 & .361 & .344 & .236 & .299 \\
\hline wbgi_gee & 1.533 & .333 & -.069 & -.495 & -.638 & -.972 \\
\hline Life Expectancy & 81.9 & 79.2 & 75.0 & 55.8 & 69.1 & 61.9 \\
\hline \# Countries in cluster & 19 & 23 & 37 & 4 & 22 & 4 \\
\hline
\end{tabular}

The clusters also indicate that communal issues have a say in shaping national identities, as well. This message is not as clear-cut in this cluster resolution. But there are two examples about what may happen. In cluster 4, where the proportion of excluded communal groups (as measured by EPR) is high, all minority-majority gaps are high, as well. In cluster 6 , the most developed country group, the proportion of exclusion is low-medium, and minorities are proud of, and attached to, their country to about the same intensity as the majorities. Yet minorities are significantly more critical about the democracy of their country, plausibly because they experience it from the perspective of relative political powerlessness of their communal group.

\section{DISCUSSION AND CONCLUSIONS}

Primordialists don't expect people's national identity constructs to change in the short term, thus probably resist the idea to work on measures that assume they do. To their credit, the measured aspects of national identity, primarily the nationalist feelings, Pride and Attachment, really show little change in the same country over time. Yet they change, and the units of time to notice some significant change of the level of the whole country seem to be measured in decades.

To date, we don't have enough data to generalize about changes on sub-national level. Nonetheless, it seems that there are shorter-term changes of the nationalist feelings of subnational groups with antithetical economic and political interests, shaped by significant power shifts, such as from right-wing to left-wing policies, from majority to minority government.

A handy method to see more variation of the national identity constructs (or nationalist attitudes) is to look at countries on different development levels. Modernists of all stripes practice this method, though they do not concur on a single notion of development and their hypotheses on 
the expected cultural change also vary. The main content of progress is always outlined in economic terms (such as GDP/capita), followed by political criteria and sometimes by social justice considerations. Our research design followed this logic, the social justice consideration was factored in to some extent by using the life expectancy measure instead of GDP, and the second democracy measure addressed distribution issues, as well.

And our expectations with regard to the outcomes were also more complicated than the classic Modernist expectation that nationalism will subside with progress. Most modernists, including developmentalists like Inglehart, expect people to re-focus their communal attachments from "primordial" ethnic/national groups onto "associational" groups such as environmentalist, LGBTQ, and professional organizations. We found a cognitive-affective convergence forming around the idea that the right question to ask is "how attached" and the right sentiment to have is attachment, rather than pride. This adds a qualitative dimension to the quantitative effacement expectation. Nationalist feelings not only subside with progress, they also change. Let us call the phenomenon a "re-definition" of these sentiments. Through its emphasis on Attachment, rather than Pride, this "re-defined" relationship with someone's primordial communities allows for effective political action within the inherited institutional frames of nationstates, a quest for win-win solutions and peaceful ways of settling conflicts. Progress also brings about higher congruence of the attitudes toward the state, of Attachment, Pride, and assessment of democratic-ness.

Ostensibly, the largest transition to the attachment-based national identity and democracyrelated national sentiments has happened in the European Union countries, which is also the area where we may find the most contented (non-dominant) minorities.

Both the factor analysis and the cluster analysis suggested that the presence, size, and wellbeing of minorities is related to the ways the population constructs their national identification. Typically, larger socio-economic inequalities and political exclusion of minorities go hand-inhand with higher national pride values, which are also more dissociated from Attachment and democracy assessments. It is hard to disentangle in this complex the impact of development and the impact of minorities, mainly that developed countries tend to have smaller minorities, and it's the developing post-colonial countries having the most communal heterogeneity.

Yet what if the country's development and the configuration of its communal landscape are not two separate phenomena, but an intermeshed idiosyncratic process? The literature includes both accusations that high heterogeneity impairs development, and newer claims that on the contrary, there is a "diversity divided" in some heterogenous countries (Gisselquist et al. 2016). In addition, radical constructivist-Modernists claim that heterogeneity itself, that is, minorities "are produced in the specific circumstances of every nation and every nationalism" 30 . Most communal features (such as ethnic belonging, language, skin color, religion), are unchangeable circumstances for individuals born in those communities; yet whether a communal feature becomes a demarcation line, a sign of "Same-ness" or "Other-ness" in a society, depends on a constellation of other factors. In Switzerland, the medieval power-sharing was organized along religious lines, and this was replaced with language-based power-sharing only in the $19^{\text {th }}$ century. The socio-political relevance of religion faded away, and the relevance of language increased. In the second half of the $20^{\text {th }}$ century, as the "ever closer union" progressed, the old traditional ethno-linguistic minorities of the West-European countries became more and more

30 Kirmayer 2019 agrees with Appadurai 2006: "minorities do not come preformed. They are produced in the specific circumstances of every nation and every nationalism." 
accommodated, while the relevance of the religion of new minorities (Muslims) increased. These examples highlight that while there are communal features of which relevance may be deemed as development-dependent (as religion is regularly considered to be), idiosyncratic factors of certain countries often interfere with the expected historical trends.

Establishing the historicity and constructed-ness of the national identity paradigms is important for both practical and moral reasons. This paper was driven by practical finalities, looking for actionable indicators of minority-majority tensions. Yet the problematic has a sensitive moral aspect. Being lower on national pride may easily be interpreted as lack of loyalty of the minorities, just consider the controversies around the kneeling of Black athletes in the U.S.! Conservative/traditional (in Inglehart's terminology, materialist) thinking endorses the monolithic Westphalian nation-state with the moral underpinning that someone should be loyal to their country, "right or wrong" (with emphasis on "even if wrong"), to the point of self-sacrifice. Since they also construct the minorities' ethnic belonging in the same strong loyalty terms, their world is conceived of as monolithic national groups (some with a state, and others without) engaged in zero-sum competition against each other. Pride is a feeling typifying competition; and lack of pride in a competitive environment is disloyalty towards their own "team." The main ideological platform promoting this worldview is international relations realism, which tends overestimate the danger that the individual countries represent for each other, and underestimate the threats people face from other, not foreign-state related sources. For instance, climate change and epidemiological threats, which need international cooperation, non-state driven terrorism, and even the unleashed global markets, which work towards making the rich richer and the poor poorer in a hectic and incalculable "casino capitalism".

A historical-constructionist approach to communal features allows for a view of the minoritymajority relationships as a matter of social justice. This approach expects loyalty from everybody only when the country is "right", and from minorities, when they have reasons to feel justly treated. Previous scholarship has already shown the decline of the unconditional, selfsacrificing loyalty to someone's country of birth. Our inquiry in the World Value Survey responses found support for the increasing importance of democracy in shaping nationalist feelings, and the importance of social advantages/disadvantages in shaping beliefs about democracy (or democratic-ness).

If we are looking for predictors of minority-majority tensions, gaps in the groups' attachment to country and assessment of its democratic-ness are viable and promising candidates. Yet this paper, an exploratory "Phase 1 trial", only supports the deservingness of this line of research. There is a lot of work to be done in order to calibrate the gap magnitudes that signal dangerous levels, and identify the development level (and/or other idiosyncratic country features) near which the predictions have decent probability. 


\section{REFERENCES}

Ariely, Gal. 2019. Measuring dimensions of national identity across countries: theoretical and methodological reflections, National Identities, DOI: 10.1080/14608944.2019.1694497

Cebotari, Victor. 2009. "National Pride among Ethnic Minority and Majority Groups in Europe. A Comparative Evidence from the European Values Survey." IMPALLA/ESPANET Conference, Luxembourg, March 6-7, 2009. Permalink: http://hdl.handle.net/10993/43952.

Cebotari, Victor. 2016. "Civic, ethnic, hybrid and atomised identities in Central and Eastern Europe", Identities, Vol. 23. Pp.648-666. 10.1080/1070289X.2015.1059338.

Elkins, Zachary; and John Sides. 2007. "Can institutions build unity in multiethnic states?", American Political Science Review, 101(4), 693-708.

Gisselquist, Rachel; Stefan Leiderer, and Miguel Niño-Zarazúa. 2016. "Ethnic heterogeneity and public goods provision in Zambia: Further evidence of a subnational 'diversity dividend'" World Development, Vol 78, Febr.2016, pp.308-323.

Greenfeld, Liah; and Jonathan Eastwood. 2007. "National Identity". In Boix, C. \& Stokes,S. (Eds), The Oxford Handbook of Comparative Politics, New York: Oxford.

Inglehart, Ronald. 2018. Cultural Evolution: People's Motivations are Changing, and Reshaping the World, Cambridge University Press.

Inglehart, Ronald. 1997. Modernization and Postmodernization: Cultural, Economic, and Political Change in 43 Societies. Princeton, NJ, Princeton University Press.

Kirmayer, Laurence J. 2019. "The Politics of Diversity: Pluralism, Multiculturalism and Mental Health", Transcultural Psychiatry 2019, Vol. 56(6) 1119-1138.

Miller, David, and Sundas Ali. 2014. "Testing the national identity argument", European Political Science Review, Vol. 6, Issue 02 (May 2014), pp $237-259$.

Moore, Margaret. 2001. The Ethics of Nationalism. Oxford University Press.

Nikolas, Margareta Mary. 1999. False Opposites in Nationalism: An Examination of the Dichotomy of Civic Nationalism and Ethnic Nationalism in Modern Europe. MA Dissertation, Monash University, Melbourne, Australia. URL: http://www.personal.ceu.hu/students/06/Nationalism_Media/nikolasfalseopposites.pdf

Ray, Subhasish. 2018. "Ethnic Inequality and National Pride", Political Psychology, Vol. 39, No. 2, pp.263-280.

Schmitter, Philippe C. 2000: How to Democratize the European Union ... And Why Bother, London, UK: Rowman \& Littlefield.

Shulman, Stephen. 2002. "Nationalist Sentiments and Globalization Preferences in Five Great Powers". Global Society, 16 (1): 47-68.

Shulman, Stephen. 2003. "Exploring the Economic Basis of Nationhood." Nationalism and Ethnic Politics 9(2): 23-49.

Sidanius, Jim, Seymour Feshbach, Shana Levin, and Felicia Pratto. 1997. "The Interface Between Ethnic and National Attachment: Ethnic Pluralism or Ethnic Dominance?" Public Opinion Quarterly 61: 103-33

Smith, Antony D. 1998. Nationalism and Modernism: A Critical Survey of Recent Theories of Nations and Nationalism. Routledge.

Solt, Frederick. (2011) Diversionary Nationalism: Economic Inequality and the Formation of National Pride. The Journal of Politics 73:3, pages 821-830.

Staerklé, Christian; Jim Sidanius; Eva G. T. Green; and Ludwin E. Molina. 2010. "Ethnic Minority-Majority Asymmetry in National Attitudes around the World: A Multilevel Analysis", Political Psychology, Vol. 31, No. 4, pp.491-519.

Steele, Liza G. 2016. ' Ethnic Diversity and Support for Redistributive Social Policies', Social Forces, Volume 94, Issue 4, June 2016, Pages 1439-1481, https://doi.org/10.1093/sf/sow021

Van Evera, Stephen. 2001. Primordialism Lives! APSA-CP: Newsletter of the Organized Section in Comparative Politics of the American Political Science Association, 12 (1): 20-22. 